\title{
USING TAGUCHI METHOD IN DEFINING CRITICAL ROTOR POLE DATA OF LSPMSM CONSIDERING THE POWER FACTOR AND EFFICIENCY
}

\author{
Ŭgur Demir, Mustafa Caner Aküner
}

Original scientific paper

This paper presents determining of critical rotor pole data of line-start permanent magnet synchronous motor (LSPMSM). The critical rotor pole data of LSPMSM considering the power factor and efficiency are investigated by using Taguchi's method. This determining process is carried out to prevent waste of time while $3 \mathrm{D}$ analysis is made. Two-dimensional (2D) dynamic finite element analysis (FEA) models are deployed to evaluate the performances of LSPMSM. To avoid the task of creating the geometry of the motor in Maxwell 3D, RMxprt has initially been used here to provide a convenient way of expediting. This study has performed 2 different ways for optimization. They were optimization using Taguchi's method and without using Taguchi's method. The method without using Taguchi method is known as a conventional method. The experimental comparisons between these ways have demonstrated that remarkable decrease in time-loss in the power factor and efficiency can be obtained by the proposed method.

Keywords: design of experiment; finite element analysis; line-start permanent magnet motor; optimization; power factor and efficiency; Taguchi

Definiranje kritičnih podataka pola rotora LSPMSM-a s obzirom na faktor snage i učinkovitosti uporabomTaguchijeve metode

Izvorni zanstveni članak

U radu se prikazuje određivanje kritičnih podataka pola rotora sinhronog motora s permanentnim magnetom (LSPMSM). Kritični podaci pola rotora LSPMSM-a s obzirom na faktor snage i učinkovitosti istražuju se pomoću Taguchi metode. Ovaj se proces određivanja provodi kako bi se spriječilo gubljenje vremena dok se radi 3D analiza. Za procjenu rada LSPMSM razvijeni su dvodimenzijski (2D) dinamički modeli analize konačnih elemenata (FEA). Da bi se izbjegao zadatak stvaranja geometrije motora u Maxwell 3D, koristio se RMxprt kako bi se osigurao prikladan način otpremanja. U radu su provedena 2 različita načina za optimizaciju. To su optimizacija primjenom Taguchi metode i bez nje. Ona bez uporabe Taguchi metode je poznata kao konvencionalna metoda. Eksperimentalne usporedbe ovih načina su pokazale da se predloženim postupkom može postići značajno smanjenje gubitka vremena kod faktora snage i učinkovitosti.

Ključne riječi: faktor snage i učinkovitosti; metoda konačnih elemenata; optimizacija; plan eksperimenta; sinhroni motor s permanentnim magnetom; Taguchi

\section{Introduction}

The Line-Start permanent magnet synchronous motor (LSPMSM) is a synchronous hybrid permanent magnet (PM) / reluctance motor that is developed for many industrial applications, including compressors, which require a high-efficiency alternative to the induction motor [1].

Earlier studies on LSPMSM appear to be mainly in the higher power application, in which large scale induction motor has been used as a baseline for the machine design [2]. A model of LSPMSM is shown in Fig. 1.

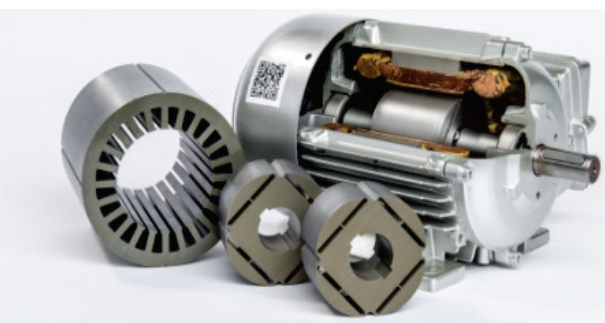

Figure 1 Line-start permanent magnet synchronous motor

In induction motors torque is developed due to the slip between stator rotating magnetic field and rotor bars. Moreover, magnetizing current is needed to produce magnetic flux. In synchronous motors magnetic flux is produced by the excitation: electromagnets or permanent magnets. Stators of induction motors and synchronous motors are practically the same. So the simplest way to obtain high both power factor and efficiency and inherent self-starting property, simplicity and ruggedness of an AC motor is installation of permanent magnets inside the induction motor rotor saving its squirrel-cage. This type of motor is called LSPMSM [3].

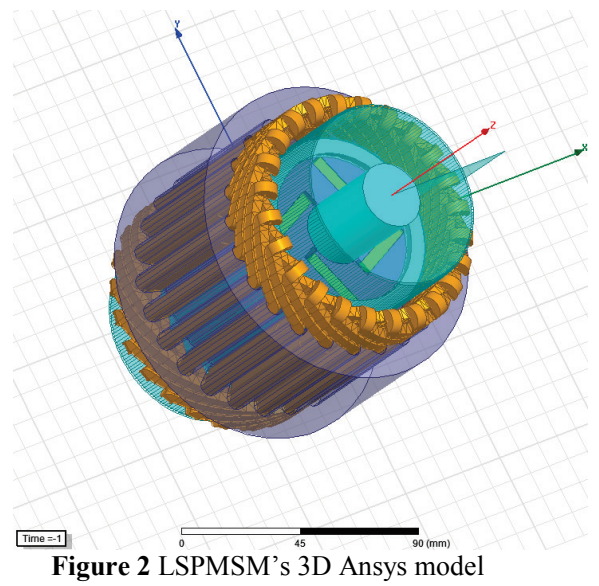

The analytical design method of LSPMSM has been investigated, and the numerical method for the design is almost correct, but it takes long time to calculate [4]. And, because there are a lot of parameters in motor design, and both objective functions and constraints for the optimization are very complex, it is impossible that all the parameters are taken into account. The small-scale optimization method is used in this paper to limit the objective functions, variables, constraints to a certain range, so some parameters in the optimization can be regarded as constant [5]. In this study, so as to define critical rotor pole data in terms of the power factor and efficiency, Ansys MAXWELL was used. Initially, 
RMxprt has been used for avoiding the task of creating the geometry of the motor in Maxwell 3D. The 3D model of LSPMSM is shown in Fig. 2.

In this paper, a process configuration that considers the power factor and efficiency is proposed to prevent waste of time while 3D analysis is made. For considering the power factor and efficiency at once, the weight function in the Taguchi's method was introduced. Finally, the proposed method was compared to the conventional method in the same conditions.

\section{Line-start permanent magnet synchronous motors (LSPMSM)}

The Line-Start permanent magnet synchronous motors (LSPMSM) have a rotor cage for induction starting and permanent magnets, providing synchronous torque. Because the LSPMSM operates as a synchronous machine, the induced currents in the rotor are much smaller than in an induction machine and thus rotor joule losses are significantly decreased. In addition, it is possible to achieve unity power factor performance, thereby reducing the stator currents and corresponding losses. This synchronous performance may of course be obtained with any synchronous permanent magnet motor. It is an additional ability of the LSPMSM to start from standstill with a fixed frequency supply which makes it an attractive proposition. Indeed, these motors are already finding use replacing synchronous reluctance motors in applications where it is important to have a number of machine operating synchronously with each other. The line starting ability allows individual motors to be taken out of service and replaced without stopping all other motors [6].

\section{Taguchi's methodology}

The optimization method used in this paper is commonly known under the name "Taguchi parameter design". In this technique, there are two types of factors that influence the functionality of a system, namely: 1) control factors and 2) noise factors. The control factors are variables that can be controlled easily, whereas the noise factors are variables that are difficult, expensive, and sometimes impossible to control. The Taguchi parameter design entails seeking the values of the control factors that make the system less sensitive to the variations of the noise factors. In other words, Taguchi optimization identifies the combinations of the control factor values that make the system robust, without eliminating the factors that cause these variations. Indeed, a pure and simple elimination of the causes of variations can be very expensive in an industrial context. There are two categories of the Taguchi optimization methods, namely: 1) the static method, which optimizes a system at a given point of operation, and 2) the general method, which optimizes a system in a wide range of operating points [7]. This last method called "dynamic response" is used in the optimization.

In general, to provide an optimal design for a product or process, the Taguchi method is used to optimize [8]. To design parameters, one of the best way is Taguchi Method. By using orthogonal array technique and signal-to-noise (SN) ratios, Taguchi method describes the best settings of parameters and also develops the performance characteristic [9]. The Taguchi method offers an organized and effective methodology for design and process optimization. It simplifies experimental plan and feasibility of study of interaction between different parameters [10].

\section{Process configuration}

The process is based on rotor pole data of LSPMSM. LSPMSM RMxprt Model is shown in Fig. 3. The rotor consists of a steel (M19) cage bar, with interior a type of magnets (XG196). The rotor geometric model for LSPMSM is shown in Fig. 4.

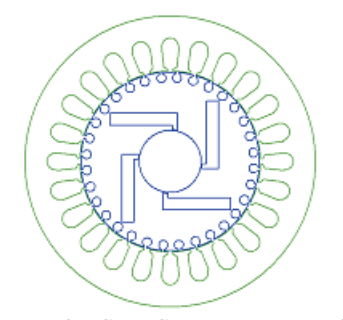

Figure 3 LSPMSM RMxprt model

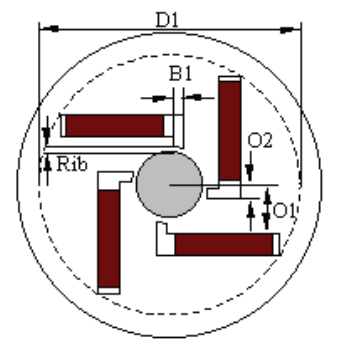

Figure 4 LSPMSM rotor geometric model

Tab. 1 shows rotor pole data for LSPMSM. These parameters are related to rotor geometric model of LSPMSM. The rotor geometric model consists of superficially magnet location and magnet duct dimensions. So the type of magnet was neglected. All parameters shown in Tab. 1 except for magnet type have been discussed for Taguchi's parameter design.

Table 1 Rotor pole data for LSPMSM

\begin{tabular}{|l|l|}
\hline \multicolumn{1}{|c|}{ Item } & \multicolumn{1}{c|}{ Descriptions } \\
\hline D1 & The limited diameter for the magnet ducts. \\
\hline O1 & A magnet duct dimension. \\
\hline O2 & A magnet duct dimension. \\
\hline B1 & A magnet duct dimension. \\
\hline Rib & $\begin{array}{l}\text { The width of the rib at the center of two } \\
\text { adjacent poles that support the bridge. }\end{array}$ \\
\hline Magnet Type & The type of magnet. \\
\hline Magnet Width & The maximum width of the magnet. \\
\hline Magnet Thickness & The maximum thickness of the magnet. \\
\hline
\end{tabular}

In order to define critical rotor parameter LSPMSM was investigated on 7 parameters of the rotor pole data in this situation. Taguchi's Parameter Design Orthogonal Array Selection Map is shown in Fig. 5. Two levels per parameter were defined and 2 levels - 7 parameters L8 was selected as the appropriate orthogonal array status in Fig. 5. 


\begin{tabular}{|c|c|c|c|c|c|c|c|c|c|}
\hline & \multicolumn{7}{|c|}{ Number of Parameters } & \multirow{2}{*}{$\begin{array}{l}\text { L8 } \\
\text { Orthogona } \\
\text { Array }\end{array}$} \\
\hline & & 2 & 3 & 4 & 5 & 6 & 7 & 8 & \\
\hline \multirow{3}{*}{ 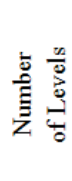 } & 2 & L4 & L4 & L8 & L8 & L8 & L8 & L12 & \\
\hline & 3 & L9 & L9 & L9 & L18 & L18 & L18 & L18 & \\
\hline & 4 & L'16 & L'16 & L'16 & L'16 & L'32 & L'32 & L'32 & \\
\hline
\end{tabular}

Figure 5 Taguchi's parameter design orthogonal array selection map

L8 orthogonal array is shown in Tab. 2. L8 shows combinations number and parameter status. Using Taguchi's method 8 experiments were performed.

Table 2 L8 orthogonal array

\begin{tabular}{|c|c|c|c|c|c|c|c|}
\hline Experiment & D1 & O1 & O2 & B1 & Rib & $\begin{array}{c}\text { Magnet } \\
\text { width }\end{array}$ & $\begin{array}{c}\text { Magnet } \\
\text { thickness }\end{array}$ \\
\hline 1 & 1 & 1 & 1 & 1 & 1 & 1 & 1 \\
\hline 2 & 1 & 1 & 1 & 2 & 2 & 2 & 2 \\
\hline 3 & 1 & 2 & 2 & 1 & 1 & 2 & 2 \\
\hline 4 & 1 & 2 & 2 & 2 & 2 & 1 & 1 \\
\hline 5 & 2 & 1 & 2 & 1 & 2 & 1 & 2 \\
\hline 6 & 2 & 1 & 2 & 2 & 1 & 2 & 1 \\
\hline 7 & 2 & 2 & 1 & 1 & 2 & 2 & 1 \\
\hline 8 & 2 & 2 & 1 & 2 & 1 & 1 & 2 \\
\hline
\end{tabular}

Number of experiments without using Taguchi's method is shown in Tab. 3. This method is known as conventional method that has been calculated as level parameter $\left(2^{7}=128\right.$ situations $)$.

Table 3 Conventional method array

\begin{tabular}{|c|c|c|c|c|c|c|c|}
\hline Tabperiment & D1 & O1 & O2 & B1 & Rib & $\begin{array}{c}\text { Magnet } \\
\text { width }\end{array}$ & $\begin{array}{c}\text { Magnet } \\
\text { thickness }\end{array}$ \\
\hline 1 & 1 & 1 & 1 & 1 & 1 & 1 & 1 \\
\hline 2 & 1 & 1 & 1 & 1 & 1 & 1 & 2 \\
\hline 3 & 1 & 1 & 1 & 1 & 1 & 2 & 1 \\
\hline 4 & 1 & 1 & 1 & 1 & 1 & 2 & 1 \\
\hline$\ldots$ & $\ldots$ & $\ldots$ & $\ldots$ & $\ldots$ & $\ldots$ & $\ldots$ & $\ldots$ \\
\hline 125 & 2 & 2 & 2 & 2 & 2 & 1 & 1 \\
\hline 126 & 2 & 2 & 2 & 2 & 2 & 1 & 2 \\
\hline 127 & 2 & 2 & 2 & 2 & 2 & 2 & 1 \\
\hline 128 & 2 & 2 & 2 & 2 & 1 & 2 & 2 \\
\hline
\end{tabular}

The defining levels for Taguchi's parameter design are limited to geometric model of the rotor. The levels represent lower and upper limits of the rotor pole data. Tab. 4 shows levels of the rotor pole data.

Table 4 Levels of Rotor Pole Data for LSPMSM

\begin{tabular}{|l|c|c|}
\hline \multicolumn{1}{|c|}{ Item } & 1 (Upper Limit) & 2 (Lower Limit) \\
\hline D1 $(\mathrm{mm})$ & 84 & 75 \\
\hline O1 $(\mathrm{mm})$ & 20 & 18 \\
\hline O2 $(\mathrm{mm})$ & 4 & 3.5 \\
\hline B1 $(\mathrm{mm})$ & 2.6 & 2.3 \\
\hline Rib $(\mathrm{mm})$ & 0,65 & 0,58 \\
\hline Magnet Type & Neglect & Neglect \\
\hline Magnet Width $(\mathrm{mm})$ & 28 & 26 \\
\hline $\begin{array}{l}\text { Magnet Thickness } \\
(\mathrm{mm})\end{array}$ & 5 & 4.8 \\
\hline
\end{tabular}

Fig. 6 shows the flowchart of the process for defining critical rotor pole data. This flowchart demonstrates defining critical rotor data both using Taguchi's method and without using Taguchi's method.
Mechanical parameter of the designed TAFPM-NN type motor is shown in Tab. 1 .

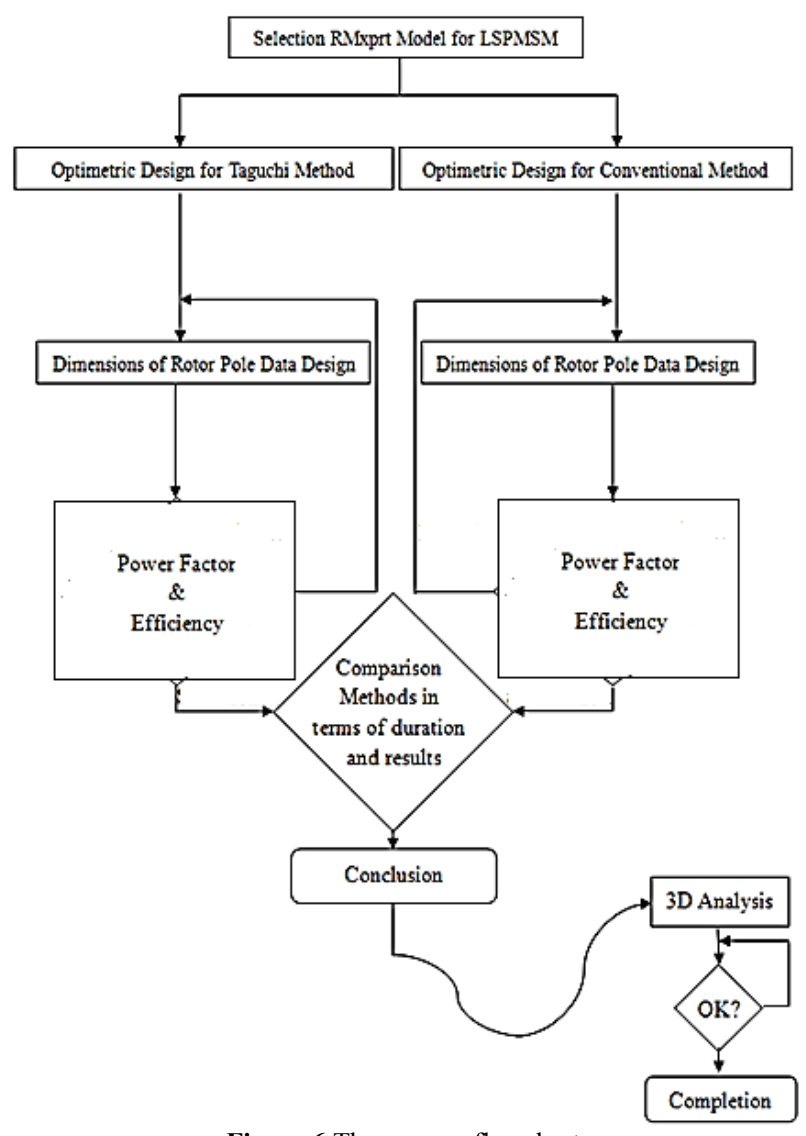

Figure 6 The process flowchart

\section{$5 \quad$ FEA modelling and analysis}

The LSPMSM has used Ansys RMxprt for modelling. The model of LSPMSM has some machine properties that are the machine types, the number of poles, the frictional loss, the windage loss and the reference speed. The model of LSPMSM has some setup properties that are the operation type, the load type, the rated output power, the rated voltage, the rated speed and the operating temperature. The mentioned setup properties and machine properties for LSPMSM are shown in Tabs. 5 and 6, respectively.

Table 5 The setup properties of LSPMSM

\begin{tabular}{|l|c|}
\hline \multicolumn{1}{|c|}{ Item } & Descriptions \\
\hline Operation Type & Motor \\
\hline Load Type & Const Power \\
\hline Rated Output Power & $1500 \mathrm{~W}$ \\
\hline Rated Voltage & $220 \mathrm{~V}$ \\
\hline Rated Speed & $3000 \mathrm{RPM}$ \\
\hline Operating Temperature & $85^{\circ} \mathrm{C}$ \\
\hline
\end{tabular}

Table 6 The Properties of LSPMSM

\begin{tabular}{|l|c|}
\hline \multicolumn{1}{|c|}{ Item } & Descriptions \\
\hline Machine Types & $\begin{array}{c}\text { Line-Start Permanent Magnet } \\
\text { Synchronous Motor }\end{array}$ \\
\hline Number of Poles & 4 \\
\hline Frictional Loss & $15 \mathrm{~W}$ \\
\hline Reference Speed & $3000 \mathrm{RPM}$ \\
\hline
\end{tabular}


The rotor and the stator of LSPMSM have some properties that are the outer diameter, the inner diameter, the length, the steel type, the number of slots and the stacking factor. The mentioned dimensions and materials of the rotor and the stator for the modelling of LSPMSM are shown in Tabs. 7 and 8, respectively.

\begin{tabular}{|l|c|}
\multicolumn{1}{|c|}{ Table 7 The properties of rotor } \\
\hline Item & Descriptions \\
\hline Outer Diameter & $98 \mathrm{~mm}$ \\
\hline Inner Diameter & $34 \mathrm{~mm}$ \\
\hline Length & $85 \mathrm{~mm}$ \\
\hline Steel Type & M19 24G \\
\hline Stacking Factor & 0,95 \\
\hline
\end{tabular}

Table 8 The properties of stator

\begin{tabular}{|l|c|}
\hline \multicolumn{1}{|c|}{ Item } & Descriptions \\
\hline Outer Diameter & $157,5 \mathrm{~mm}$ \\
\hline Inner Diameter & $98,4 \mathrm{~mm}$ \\
\hline Length & $85 \mathrm{~mm}$ \\
\hline Steel Type & M19 24G \\
\hline Stacking Factor & 0,95 \\
\hline Number of Slot & 24 \\
\hline
\end{tabular}

According to L8 orthogonal array shown in Tab. 2, totally, 8 experiments were performed. The results acquired from the $1^{\text {st }}$ experiment and the $7^{\text {th }}$ experiment in Taguchi's method are shown in Tab. 9.

Table 9 The results from $1^{\text {st }}$ experiment and $7^{\text {th }}$ experiment in taguchi's method

\begin{tabular}{|c|c|c|c|c|}
\hline Exp. No. & $\begin{array}{c}\text { Air gap } \\
\text { power / } \\
\mathrm{kW}\end{array}$ & Power factor & Efficiency & $\begin{array}{c}\text { Time } \\
\text { duration } \\
/ \mathrm{s}\end{array}$ \\
\hline 1 & 7,189 & 0,508595 & 0,947244 & 1 \\
\hline 2 & 6,791 & 0,561385 & 0,950696 & 1 \\
\hline 3 & 6,795 & 0,561442 & 0,950651 & 1 \\
\hline 4 & 7,105 & 0,506270 & 0,947370 & 1 \\
\hline 5 & 5,999 & 0,750580 & 0,919891 & 1 \\
\hline 6 & 6,310 & 0,754689 & 0,916033 & 1 \\
\hline 7 & 6,228 & 0,753272 & 0,916781 & 1 \\
\hline 8 & 6,068 & 0,751854 & 0,919263 & 1 \\
\hline
\end{tabular}

The results shown in Tab. 9 are related to Taguchi's method and consist of the maximum air gap power, the power factor, the efficiency and the time duration for analysis.

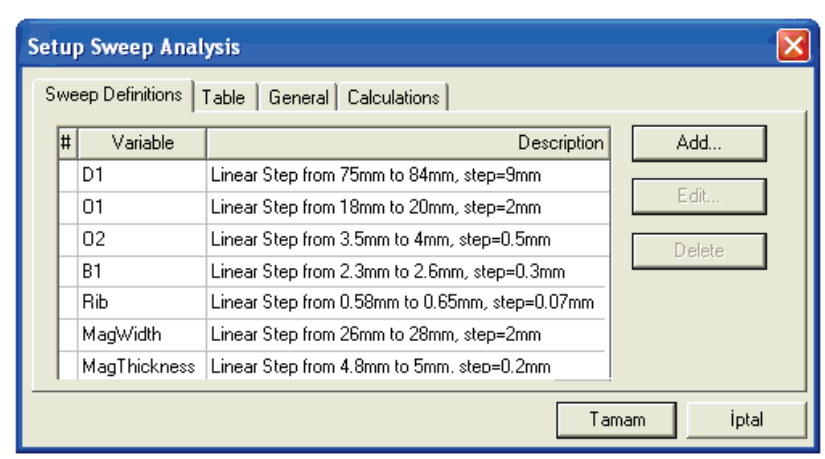

Figure 7 The sweep configuration for conventional method

On the other hand, the conventional method array shown in Fig. 7 consists of 128 experiments. These experiments were performed using optimetric tool in Ansys Maxwell RMxprt. The optimetric tool configuration is related to conventional method shown in
Fig. 7. The results acquired from the $1^{\text {st }}$ experiment and the $128^{\text {th }}$ experiment are shown in Tab. 10 .

The results shown in Tab. 10 are related to the conventional method consist of the maximum air gap power, the power factor, the efficiency and the time duration for analysis. In Eq. (1) shown in the bigger-thebetter $\mathrm{S} / \mathrm{NBTB}$, where, $y_{i}$ is the measured value and $n$ is the measurement number.

$$
\frac{S}{N_{\mathrm{BTB}}}=-10 \cdot \log \left(\frac{1}{n} \sum_{i=1}^{n} \frac{1}{y_{i}^{2}}\right) .
$$

Table 10 The results from $1^{\text {st }}$ experiment and $128^{\text {th }}$ experiment in conventional method

\begin{tabular}{|c|c|c|c|c|}
\hline Experiment & $\begin{array}{c}\text { Air gap } \\
\text { power / } \\
\mathrm{kW}\end{array}$ & Power factor & Efficiency & $\begin{array}{c}\text { Time } \\
\text { duration / s }\end{array}$ \\
\hline 1 & 7,1894 & 0,508595 & 0,947244 & 0,83 \\
\hline 2 & 7,3433 & 0,512806 & 0,947046 & 0,83 \\
\hline 3 & 6,7361 & 0,559740 & 0,950766 & 0,83 \\
\hline 4 & 6,8532 & 0,563135 & 0,950560 & 0,83 \\
\hline 5 & 7,1020 & 0,506177 & 0,947375 & 0,83 \\
\hline 6 & 7,2534 & 0,510389 & 0,947187 & 0,83 \\
\hline$\ldots$ & $\ldots$ & $\ldots$ & $\ldots$ & $\ldots$ \\
\hline 123 & 6,2728 & 0,753973 & 0,916328 & 0,83 \\
\hline 124 & 6,4439 & 0,757099 & 0,914934 & 0,83 \\
\hline 125 & 6,5100 & 0,740104 & 0,934005 & 0,83 \\
\hline 126 & 5,9815 & 0,750192 & 0,920025 & 0,83 \\
\hline 127 & 6,2226 & 0,753145 & 0,916821 & 0,83 \\
\hline 128 & 6,3918 & 0,756282 & 0,915447 & 0,83 \\
\hline & & & & \\
\hline
\end{tabular}

The signal to noise ratio $(S / N)$ of the power factor and the efficiency in Taguchi's method are shown in Tab. 11 by calculating the Eq. (1).

Table 11 The $S / N$ of the power factor and the efficiency in Taguchi's method

\begin{tabular}{|c|c|c|c|c|}
\hline Exp. No. & $\begin{array}{c}\text { Power } \\
\text { Factor }\end{array}$ & $\begin{array}{c}S / N_{\mathrm{BTB}_{-}} \\
\text {PowerFactor }\end{array}$ & Efficiency & $\begin{array}{c}S / N_{\mathrm{BTB}_{-}} \\
\text {Efficiency }\end{array}$ \\
\hline 1 & 0,508595 & $-5,872552$ & 0,947244 & $-0,470762$ \\
\hline 2 & 0,561385 & $-5,014783$ & 0,950696 & $-0,439166$ \\
\hline 3 & 0,561442 & $-5,013902$ & 0,950651 & $-0,439577$ \\
\hline 4 & 0,506270 & $-5,912356$ & 0,947370 & $-0,469607$ \\
\hline 5 & 0,750580 & $-2,492060$ & 0,919891 & $-0,725272$ \\
\hline 6 & 0,754689 & $-2,444639$ & 0,916033 & $-0,761777$ \\
\hline 7 & 0,753272 & $-2,460963$ & 0,916781 & $-0,754687$ \\
\hline 8 & 0,751854 & $-2,477329$ & 0,919263 & $-0,731204$ \\
\hline
\end{tabular}

The values shown in Tab. 11 are related to the analysis of the relative effect of the different parameters. To determine the effect each variable has on the output, the signal-to-noise ratio, or the $\mathrm{S} / \mathrm{N}$ number, needs to be calculated for each experiment conducted. The effect of each variable to the power factor and the efficiency are shown in Tabs. 12 and 13, respectively. The response of the Taguchi's method for the power factor and the efficiency consists of the level 1 , the level 2, the delta and the rank. The level 1 and the level 2 were calculated by using of the state of the upper limit and the lower limit of the rotor pole data for LSPMSM. The delta is the difference in the level 1 and the level 2. The rank of the rotor pole data was aligned by the delta. 
Table 12 The Response of Taguchi's method for the power factor

\begin{tabular}{|c|c|c|c|c|}
\hline Factor / mm & Level 1 & Level 2 & Delta & Rank \\
\hline D1 & $-5,453400$ & $-2,468748$ & 2,984651 & 1 \\
\hline O1 & $-3,956010$ & $-3,966137$ & 0,010127 & 5 \\
\hline O2 & $-3,956408$ & $-3,965739$ & 0,009330 & 6 \\
\hline B1 & $-3,959871$ & $-3,962277$ & 0,002406 & 7 \\
\hline Rib & $-3,952107$ & $-3,970041$ & 0,017933 & 4 \\
\hline Magnet width & $-4,188576$ & $-3,733572$ & 0,455003 & 2 \\
\hline Magnet thickness & $-4,172629$ & $-3,749519$ & 0,423110 & 3 \\
\hline
\end{tabular}

In the conventional method, Eq. (1) was used for calculating the signal to noise ratio $(\mathrm{S} / \mathrm{N})$ of the power factor and the efficiency. The $S / N$ belonging to the power factor and the efficiency are shown in Figs. 8 to 11, respectively. To acquire the response of the conventional method, level 1 and level 2 were calculated by Figs. 8 and 9. The response of the conventional method for the power factor and efficiency is shown in Tabs. 14 and 15, respectively.

Table 13 The Response of Taguchi's method for the efficiency

\begin{tabular}{|c|c|c|c|c|}
\hline Factor / mm & Level 1 & Level 2 & Delta & Rank \\
\hline D1 & $-0,45477$ & $-0,74323$ & 0,288456 & 1 \\
\hline O1 & $-0,59924$ & $-0,59876$ & 0,000475 & 5 \\
\hline O2 & $-0,59895$ & $-0,59905$ & 0,000103 & 7 \\
\hline B1 & $-0,59757$ & $-0,60043$ & 0,002863 & 4 \\
\hline Rib & $-0,60083$ & $-0,59718$ & 0,003646 & 3 \\
\hline Magnet width & $-0,59921$ & $-0,59880$ & 0,000409 & 6 \\
\hline Magnet thickness & $-0,61420$ & $-0,58380$ & 0,030403 & 2 \\
\hline
\end{tabular}

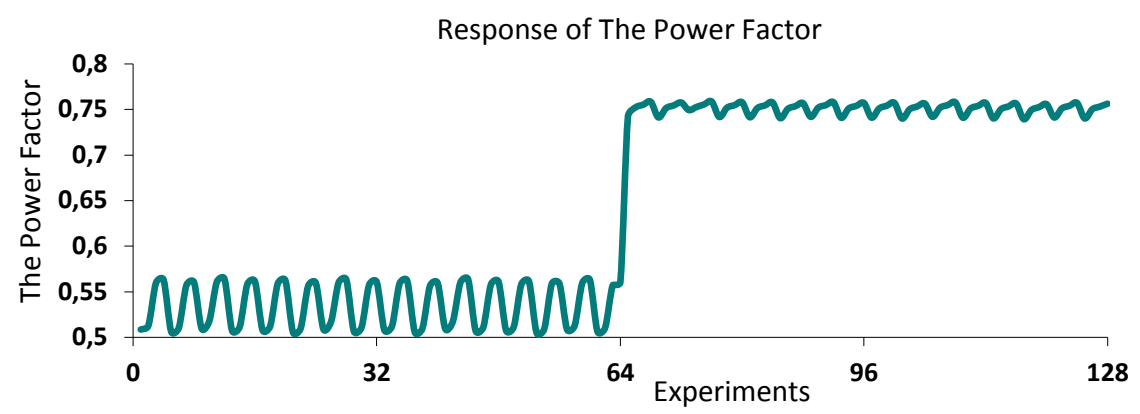

Figure 8 Response of the power factor in conventional method

Response of The $S / N_{\text {BTB_Power Factor }}$

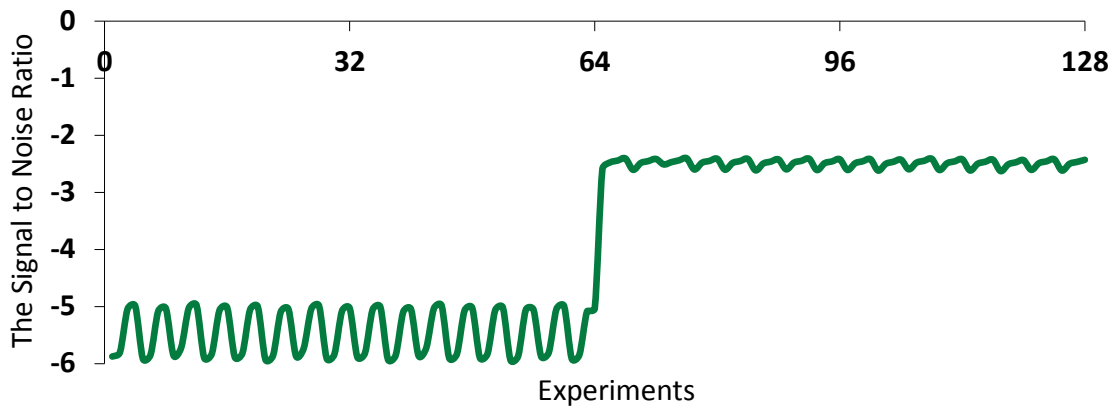

Figure 9 Response of the power factor in conventional method

Table 14 The Response of conventional method for the power factor

\begin{tabular}{|c|c|c|c|c|}
\hline Factor / mm & Level 1 & Level 2 & Delta & Rank \\
\hline D1 & $-5,443634$ & $-2,487788$ & 2,955846 & 1 \\
\hline O1 & $-3,960004$ & $-3,9714172$ & 0,011413 & 7 \\
\hline O2 & $-3,959845$ & $-3,9715765$ & 0,011731 & 6 \\
\hline B1 & $-3,974048$ & $-3,9265781$ & 0,047470 & 4 \\
\hline Rib & $-3,951236$ & $-3,9801858$ & 0,028950 & 5 \\
\hline Magnet width & $-4,197077$ & $-3,7343449$ & 0,462732 & 2 \\
\hline Magnet thickness & $-4,000587853591610$ & $-3,9308338$ & 0,069754 & 3 \\
\hline
\end{tabular}

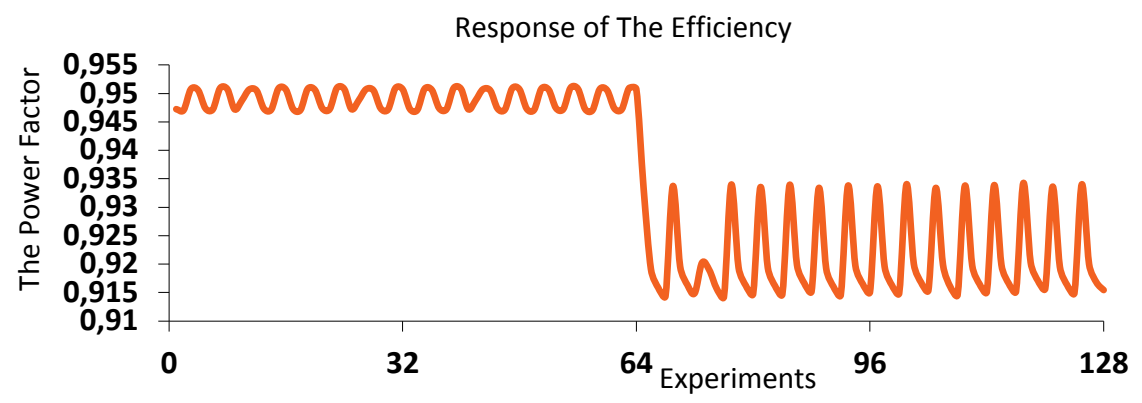

Figure 10 Response of the efficiency in conventional method 


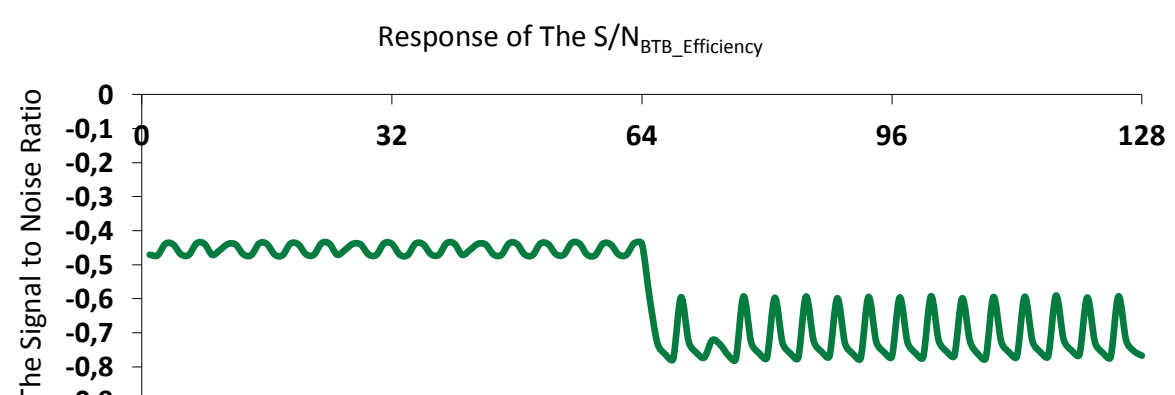

Experiments

Figure 11 The $\mathrm{S} / \mathrm{N}$ of the power factor in conventional method

Table 15 The response of conventional method for the efficiency

\begin{tabular}{|c|c|c|c|c|}
\hline Factor / mm & Level 1 & Level 2 & Delta & Rank \\
\hline D1 & $-0,454046$ & $-0,7153510$ & 0,261304 & 1 \\
\hline O1 & $-0,586439$ & $-0,5829575$ & 0,003482 & 6 \\
\hline O2 & $-0,586192$ & $-0,5832048$ & 0,002987 & 7 \\
\hline B1 & $-0,583582$ & $-0,5886895$ & 0,005107 & 4 \\
\hline Rib & $-0,586704682894868$ & $-0,5826923$ & 0,004012 & 5 \\
\hline Magnet width & $-0,567466703231988$ & $-0,6019302$ & 0,034464 & 3 \\
\hline Magnet thickness & $-0,567445307975394$ & $-0,6019516$ & 0,034506 & 2 \\
\hline
\end{tabular}

\section{Comparison between proposed method and classic method}

In order to confirm the results acquiring from Taguchi's method, the ranking of the Taguchi's method was compared to the ranking of the conventional method. Primarily, the critical rotor pole data of LSPMSM considering the power factor and the efficiency must be determined. When the delta and the ranking shown in Tab. 12 and in Tab. 14 were taken into account, the O1, the $\mathrm{O} 2$, the $\mathrm{B} 1$ and the Rib have very low values in comparison with the D1, the magnet width and the magnet thickness. Therefore, the $\mathrm{O} 1$, the $\mathrm{O} 2$, the $\mathrm{B} 1$ and the Rib were neglected for the power factor. While Table 13 and Tab. 15 were dealt, The O1, the O2, the B1, the Rib and the magnet thickness were neglected for the efficiency. When the power factor ranking shown in Tab. 12 was compared with the power factor ranking shown in Tab. 14, a significant deviation in the ranking wasn't observed for the D1, the magnet width and the magnet thickness which were defined critical parameter. In the same way, when the efficiency ranking shown in Table 1 was compared with the power factor ranking shown in Tab. 15, a significant deviation in the ranking was not observed for the D1 and the magnet thickness which were defined as critical parameters.

After the verification process, from the results, it is evident that the Taguchi's method gives good agreement with the conventional method. The Taguchi's method is a very attractive method and was observed in the terms of the total time duration.

\section{Conclusion}

This paper presents the Taguchi's method for LSPMSM. The Taguchi's method and the conventional method were deployed by using an FEM analysis. Then, the Taguchi's method was compared with the conventional method. These studies have proved that Taguchi's method can be used in the defining critical rotor pole data of LSPMSM, and, the Taguchi's method saves remarkable time in comparison with the conventional method.

\section{References}

[1] Miller, T. J. E.; Popescu, M.; Cossar, C.; McGilp, M.; Strappazzon, G.; Trivillin, N.; Santarossa, R. Line-start permanent-magnet motor single-phase steady-state performance analysis. // IEEE Trans. Ind. Appl. 40, 2(2004), pp. 516-525. DOI: 10.1109/TIA.2004.824492

[2] Fei, W.; Luk, P. C. K.; Ma, J.; Shen, J. X.; Yang, G. A High-Performance Line-Start Permanent Magnet Synchronous Motor Amended From a Small Industrial Three-Phase Induction Motor. // IEEE Trans. on Magnetics. 45, 10(2009), pp. 4724-4727. DOI: 10.1109/TMAG.2009.2022179

[3] Gwodziewicz, M.; Zawilak, J. Single-Phase Line Start Permanent Magnet Synchronous Motor. // Zeszyty Problemowe - Maszyny Elektryczne. 93, 5(2011), pp. 2529.

[4] Kim, W.; Kim, K.; Kim, S.; Kang, D.; Go, S.; Lee, H.; Chun, Y.; Lee, J. A Study on the Optimal Rotor Design of LSPM Considering the Starting Torque and Efficiency. // IEEE Trans. on Magnetics. 45, 3(2009), pp. 1808-1811. DOI: 10.1109/TMAG.2009.2012757

[5] Rui, Z.; Qunjing, W.; Guoli, L.; Cong, P.; Guanghui, F. Optimal Design of Single-phase Induction Motor based on MAXWELL 2D Rmxprt. // International Conference on Electrical Machines and Systems (ICEMS), Oct. 2010, pp. 1367-1370.

[6] Knight, A. M.; McClay, C. I. The design of high-efficiency linestart motors. // IEEE Trans. Ind. Appl. 36, 6(2000), pp. 1555-1562. DOI: 10.1109/28.887206

[7] Omekanda, A. Robust Torque and Torque-per-Inertia Optimization of a Switched Reluctance Motor Using the Taguchi Methods. // IEEE Trans. Ind. Appl.. 42, 2(2006), pp. 473-478. DOI: 10.1109/TIA.2006.870031

[8] Xu, Z.; Wang, S.; Zhang, Z.; Chin, T.; Sung, C. Optimization of Magnetizing Parameters for Multipole Magnetic Scales Using the Taguchi Method. // IEEE Transaction on Magnetics. 51, 11(2015). DOI: 10.1109/TMAG.2015.2458017 
[9] Wang, H.; Geng, Q.; Qiao, Z. Parameter Tuning of Particle Swarm Optimization by Using Taguchi Method and Its Application to Motor Design. // IEEE International Conference on Information Science and Technology (ICIST), Apr. 2014, pp. 722-726. DOl: 10.1109/icist.2014.6920579

[10] Saurabh; Jassi, J. S.; Mohammad, A.; Singh, D. P.; Jafri, H. Z. Machining parameter optimization using Taguchi Approach. // IEEE International Conference on Futuristic Trends on Computational Analysis and Knowledge Management (ABLAZE), Feb. 2015, pp. 90-95.

\section{Authors' addresses}

\section{Ŭ̈ur Demir}

Marmara University,

Mechatronics Engineering Department,

Kadikoy, 34722 Istanbul, Turkey

E-mail: ugur-demir@outlook.com

\section{Mustafa Caner Akuner}

Department of Mechatronic Engineering,

Technology Faculty Marmara University,

34722 Istanbul, Turkey

E-mail: akuner@marmara.edu.tr 